\title{
Short communication: Chemical composition, fatty acid composition, and sensory characteristics of Chanco cheese from dairy cows supplemented with soybean and hydrogenated vegetable oils
}

\author{
E. Vargas-Bello-Pérez, ${ }^{* 1}$ K. Fehrmann-Cartes, ${ }^{*}$ G. Íñiguez-González, ${ }^{*}$ P. Toro-Mujica, ${ }^{*}$ and P. C. Garnsworthy† \\ *Departamento de Ciencias Animales, Facultad de Agronomía e Ingeniería Forestal, Pontificia Universidad Católica de Chile, Santiago, Chile, \\ Casilla 306, C.P. 6904411 \\ †The University of Nottingham, Sutton Bonington Campus, Loughborough, LE12 5RD, United Kingdom
}

\begin{abstract}
Lipid supplements can be used to alter fatty acid (FA) profiles of dairy products. For Chanco cheese, however, little information is available concerning effects of lipid supplements on sensorial properties. The objective of this study was to examine effects of supplementation of dairy cow diets with soybean (SO) and hydrogenated vegetable (HVO) oils on chemical and FA composition of milk and cheese and sensory characteristics of cheese. Nine multiparous Holstein cows averaging $169 \pm 24 \mathrm{~d}$ in milk at the beginning of the study were used in a replicated $(\mathrm{n}=3) 3 \times 3$ Latin square design that included 3 periods of $21 \mathrm{~d}$. All cows received a basal diet formulated with a 56:44 forage:concentrate ratio. Dietary treatments consisted of the basal diet (control; no fat supplement), and the basal diet supplemented with SO (unrefined oil; $500 \mathrm{~g} / \mathrm{d}$ per cow) and HVO (manufactured from palm oil; $500 \mathrm{~g} / \mathrm{d}$ per cow). Milk fat yield was lower with HVO compared with control and SO. Cheese chemical composition and sensory profile were not affected by dietary treatment. Vaccenic (C18:1 trans-11) and oleic (C18:1 cis-9) acids were higher for SO than for control and HVO. Compared with control and HVO, SO decreased saturated FA and increased monounsaturated FA. The thrombogenic index of milk and cheese produced when cows were fed $\mathrm{SO}$ was lower than when cows were fed on control and HVO. The outcome of this study showed that, compared with control and HVO, supplementing dairy cow diets with SO improves milk and cheese FA profile without detrimental effects on the chemical composition of milk and cheese and the sensory characteristics of cheese.
\end{abstract}

Key words: cheese, milk, sensory characteristics, oil supplement

\footnotetext{
Received September 8, 2014.

Accepted October 9, 2014.

${ }^{1}$ Corresponding author: evargasb@uc.cl
}

\section{Short Communication}

Interest in bovine milk components that may be able to improve human health, such as fat, has been noted (Shingfield et al., 2013), particularly on the prevention of atherosclerosis, hypercholesterolemia, and other factors related to cardiovascular disease (Salter, 2013). Milk contains some FA that could be beneficial to human health, such as the CLA isomer C18:2 cis9,trans-11 (RA; rumenic acid) and the trans fatty acid C18:1 trans-11 (VA; vaccenic acid; Lock and Bauman, 2004). Modifying the dairy cow diet is a rapid and practical way to increase the milk concentration of beneficial FA from a human health standpoint (Stamey et al., 2012). Dietary soybean oil (SO) has been shown to increase VA and total C18:1 trans FA concentrations in milk (Lock and Garnsworthy, 2002) and cheese (Allred et al., 2006) of dairy cows. Hydrogenated vegetable oils (HVO) are used to increase the energy density of high-producing dairy cow diets (Kargar et al., 2012) and can increase milk and fat yields in grazing systems (Schroeder et al., 2002), leading to a high yield of C16:0 and C18:0 FA.

Sensory characteristics are of great importance for consumer acceptability of dairy products. Previous studies (in the Americas and Europe) on bovine cheeses obtained from milk from cows fed different dietary PUFA sources, such as extruded soybeans (Khanal et al., 2005), extruded linseeds (Sympoura et al., 2009), fish and sunflower oils (Jones et al., 2005), fish and soybean oils (Lynch et al., 2005), rapeseed oil (Ryhänen et al., 2005), and calcium salts of palm and fish oil in combination with soybean products (Allred et al., 2006), have reported minor effects on the sensory properties of cheese.

Chanco cheese, one of the most important bovine cheeses in Chile, is a semihard and greasy cheese (Brito et al., 2003). To our knowledge, no study has been published reporting the effects of dietary supplementation with SO and HVO to dairy cows on the sensorial properties of Chanco cheese. Thus, the objectives of 
the present study were to examine effects of supplementing 2 sources of FA-SO (unsaturated) and HVO (saturated) - in dairy cow diets on the chemical and FA composition of milk and cheese as well as the sensory characteristics of Chanco cheese.

Nine multiparous Holstein cows averaging $169 \pm$ 24 DIM (means \pm SD) at the beginning of the study were used in a replicated $(\mathrm{n}=3) 3 \times 3$ Latin square design that included 3 periods of $21 \mathrm{~d}$. Average BW of the cows at the onset of the experiment was $583.6 \pm$ 80.4 (means \pm SD) with a BCS of $3 \pm 0.5$ (means \pm $\mathrm{SD}$; scored on a 5-point scale). Body weights and BCS were recorded at the beginning of the trial and the end of each experimental period. Cows were individually fed a TMR at a fixed rate (so that cows consumed all their feed and treatment) once daily (at $0930 \mathrm{~h}$ ). All cows received a basal diet formulated with a 56:44 forage (alfalfa hay and corn silage)-to-concentrate ratio to meet the requirements of a $600-\mathrm{kg}$ dairy cow producing 30 L per day (NRC, 2001). Dietary treatments consisted of a basal diet (control; no fat supplement) and fat-supplemented diets containing SO (unrefined oil; $500 \mathrm{~g} / \mathrm{d}$ per cow) and HVO (manufactured from palm oil; $500 \mathrm{~g} / \mathrm{d}$ per cow; Table 1$)$. The SO contained $25 \mathrm{~g} / 100 \mathrm{~g}$ of $\mathrm{C} 18: 1 \mathrm{cis}-9$ and $51 \mathrm{~g} / 100 \mathrm{~g}$ of $\mathrm{C} 18: 2$ cis $\mathrm{n}-6$, whereas HVO contained $47 \mathrm{~g} / 100 \mathrm{~g}$ of C16:0 and $43 \mathrm{~g} / 100 \mathrm{~g}$ of C18:0. A mixer wagon was used to mix forage and concentrate. Oils were administrated separately and mixed manually into the daily ration for each cow. Animals were housed in individual stalls $(2.4 \times 6 \mathrm{~m})$ and had continuous access to water. Cows were milked 3 times daily (0700, 1500, and $2200 \mathrm{~h}$ ). Milk yields were recorded daily and individual samples were taken from the morning milking on d 20 of each period. Milk production during the last $10 \mathrm{~d}$ of each period was used for statistical analysis. Milk samples $(150 \mathrm{~mL} / \mathrm{cow})$ were preserved with potassium dichromate $(300 \mathrm{mg})$ and stored at $-20^{\circ} \mathrm{C}$ for later analysis. Milk samples were analyzed for fat content (Gerber method; British Standards Institution 696; BSI, 1969), CP (16.036; Kjeldahl N × 6.38), ash (16.035), and TS (16.032) according to the AOAC (1984) procedures.

A traditional cheese-making technique was used to make Chanco cheese. Milk collected on d 21 (at 0700 h) was pooled from 3 cows within the same treatment and period and made into cheese without standardizing for fat content. Cheeses were made in a pilot plant as follows: $15 \mathrm{~L}$ of milk per treatment per period were heated to $36^{\circ} \mathrm{C}$, and commercial rennet was added to curdle the milk at $38^{\circ} \mathrm{C}$. No starter culture was added for cheese making, and sodium chloride in cold water $(6$ $\mathrm{g}$ of $\mathrm{NaCl} / 100 \mathrm{~mL}$ of $\mathrm{H}_{2} \mathrm{O}$ ) was added to aid coagulation. After milk had clotted (45 min), the curd was cut to the size of a corn grain and then the vat temperature was gradually increased to $37^{\circ} \mathrm{C}$ at a rate of $1^{\circ} \mathrm{C} / 3 \mathrm{~min}$ and maintained for $15 \mathrm{~min}$. The curd was stirred to remove the whey and favor grain aggregation. Curds were placed into $250-\mathrm{g}$ molds and pressed in a horizontal mechanical press. Cheeses were salted in brine at $10^{\circ} \mathrm{C}$ for $12 \mathrm{~h}$ and then transferred to a ripening room where they remained at a temperature of 9 to $10^{\circ} \mathrm{C}$ and $\sim 90 \%$ relative humidity for $14 \mathrm{~d}$. Four cheeses per treatment per period were allowed to mature for $14 \mathrm{~d}$. Two cores of 1 cheese per treatment per period were obtained for chemical composition and FA analyses. Cheeses were analyzed for moisture content by AOAC International (2000) method 934.01 and for ash content by AOAC (1990) method 942.05. The fat content of cheese samples was determined using the Gerber method, and the total protein content was determined by measuring the total nitrogen, according to AOAC (1990) Kjeldahl method 976.06, and converting this value to the protein content by multiplying by 6.38 . Three cheeses per treatment per period were vacuum-packaged in airtight plastic bags and sent to the sensory laboratory (Instituto de Nutrición y Tecnología de los Alimentos, Santiago, Chile) at $14 \mathrm{~d}$ of aging. All assessments were carried out in individual booths designed according to the international standard, ISO 8589 (ISO, 2007). Judges were not provided information regarding the treatment of each sample in any testing session. The panel was composed of 12 judges who had several years of experience in sensory evaluation and were trained for evaluation of bovine cheeses. Before evaluation, the panel used commercial Chanco cheese in a pretesting session to standardize the panel's definitions for the sensorial attributes. Evaluations considered the following attributes according to the ISO 13299 criteria (ISO, 2003): color homogeneity, holes, overall odor, ripe cheese odor, cow milk odor, saltiness, acidity, bitterness, overall flavor, ripe cheese flavor, sharpness, toughness,

Table 1. Ingredient and chemical composition of control, soybean oil (SO), and partially hydrogenated vegetable oil (HVO) dietary treatments

\begin{tabular}{lccr}
\hline & \multicolumn{3}{c}{ Diet } \\
\cline { 2 - 4 } $\begin{array}{l}\text { Ingredient composition } \\
\text { (\% of DM) }\end{array}$ & Control & SO & HVO \\
\hline Alfalfa hay & 17.0 & 16.6 & 16.6 \\
Corn silage & 18.0 & 17.5 & 17.5 \\
High-moisture corn & 10.0 & 9.7 & 9.7 \\
Soybean hulls & 34.0 & 33.1 & 33.1 \\
Wheat bran & 19.0 & 18.5 & 18.5 \\
Vitamin and mineral premix ${ }^{1}$ & 2.0 & 2.0 & 2.0 \\
SO & - & 2.6 & - \\
HVO & - & - & 2.6 \\
\hline
\end{tabular}

${ }^{1}$ Contained per kilogram: 25, $000 \mathrm{mg}$ of P; $80,000 \mathrm{mg}$ of Ca; $25,000 \mathrm{mg}$ of $\mathrm{Mg} ; 1,612 \mathrm{mg}$ of $\mathrm{S} ; 300,000 \mathrm{IU}$ of vitamin $\mathrm{A} ; 50,000 \mathrm{IU}$ of vitamin $\mathrm{D}_{3}$, and $1,600 \mathrm{IU}$ of vitamin $\mathrm{E}$. 
Table 2. Sensory descriptors and definitions from the appearance, aroma, flavor and texture evaluation of Chanco cheese

\begin{tabular}{ll}
\hline Attribute & Definition \\
\hline Color homogeneity & Appearance, degree of color homogeneity \\
Holes & Appearance, total amount of holes on the inner cheese surface, regardless of source \\
Overall aroma intensity & Aroma, total overall aroma intensity of the sample \\
Ripe Chanco aroma intensity & Aroma, intensity of aromas typically associated with a Chanco cheese ripened for 21 d \\
Cow milk aroma & Aroma, aromatics associated with fresh milk \\
Overall flavor intensity & Flavor, intensity of the overall product flavor \\
Ripe cheese flavor & Flavor, intensity of flavor associated with Chanco cheese ripened for $21 \mathrm{~d}$ \\
Salty & Flavor, basic taste generated by salts \\
Acid & Flavor, basic taste generated by acids \\
Bitter & Flavor, basic taste generated by caffeine \\
Sharpness/astringency & Flavor, chemical feeling, harsh, drying, puckering sensation on mouth surfaces elicited by dry red wine \\
Toughness/chewiness & Texture, degree of chewing needed to break up the sample \\
Graininess/crumbliness & Texture, the extent to which cheese structure breaks up in the mouth during the first 2 to 3 chews \\
Screeching & Texture, intensity of the sound made when the sample is chewed \\
Free moisture release & Texture, the degree of moistness sensed in the mouth during mastication \\
Greasiness/oiliness & Texture, greasy mouth feel of any kind \\
\hline
\end{tabular}

graininess, screeching, moisture, and greasiness (Table 2). The judges evaluated all samples (cheese slices of 1 $\mathrm{cm}$ of approximately $10 \mathrm{~g}$ ) in monadic sequential way, scoring the attributes on a continuous unstructured line intensity scale ranging from 0 to 9 (none and very-high intensity) and anchored at both ends with extremes for each attribute.

Lipids from oils, milk, and cheese were analyzed using a GC system (Shimadzu Scientific Instruments AOC-20s, Columbia, MD) equipped with a 100-m column (Rtx column; $100 \mathrm{~m} \times 0.32 \mathrm{~mm} \times 0.20 \mathrm{um}$ ). Fatty acid peaks were identified by using a FAME standard (Supelco 37 Component FAME mix, Bellefonte, PA), reference standards for C18:1 trans-11 and C18:1 cis9,trans-11 (Nu-Chek Prep Inc., Elysian, MN) methyl esters were used. Because VA can be converted to RA in the mammary gland through the enzyme $\Delta^{9}$-desaturase (Lock and Bauman, 2004), the $\Delta^{9}$-desaturase index was calculated for selected milk FA using product-tosubstrate ratios of FA. Some FA can prevent or provoke atherosclerosis and coronary thrombosis in humans; thus, the atherogenic and thrombogenic indices were calculated according to Ulbricht and Southgate (1991) equations, with $\mathrm{C} 12: 0, \mathrm{C} 14: 0$, and $\mathrm{C} 16: 0$ as atherogenic and C14:0, C16:0, and C18:0 as thrombogenic FA.

Data were analyzed as a replicated $(\mathrm{n}=3) 3 \times 3$ Latin Square using the GenStat (12th ed.) statistical package (VSN International Ltd., Oxford, UK). The fixed effects were experimental periods and treatments and the random effect was the cow. When significant treatment effects were detected, means were separated using Tukey test. Probability of $P<0.05$ was used to determine significant differences among means.

Body weight $(602 \pm 5 \mathrm{~kg})$, BCS $(3.1 \pm 0.1)$, and SCC $\left(94 \pm 15 \times 10^{3} / \mathrm{mL}\right)$ were similar across treatments. Lower $3.5 \%$ FCM (25.7 and 24.4 vs. $21.5 \mathrm{~kg} / \mathrm{d}$; control and SO vs. HVO) and ECM (20.7 and 19.6 vs. 17.4 $\mathrm{kg} / \mathrm{d}$; control and SO vs. HVO) yields were observed when cows were fed HVO than when cows were fed control and SO; this may be explained by lower milk fat content rather than milk yield. Milk yield $(26.3 \pm$ $1.0 \mathrm{~kg} / \mathrm{d}$ ) and milk composition were not affected by dietary treatment; this is in agreement with $\mathrm{Bu}$ et al. (2007), who supplemented dairy cow diets with $4 \%$ SO. However, supplementing $500 \mathrm{~g} / \mathrm{cow}$ per day (Zheng et al., 2005) or $2.7 \%$ (Jacobs et al., 2011) of SO to dairy cows can reduce milk fat content. In the current study, compared with control $(0.87 \mathrm{~kg} / \mathrm{d})$ and $\mathrm{SO}(0.78 \mathrm{~kg} / \mathrm{d})$, HVO $(0.65 \mathrm{~kg} / \mathrm{d})$ reduced milk fat yield. Hydrogenated vegetable oils can reduce milk fat yield at $454 \mathrm{~g} / \mathrm{cow}$ per day (Selner and Schultz, 1980); however, in grazing dairy cows, supplementation of HVO $(1,000 \mathrm{~g} / \mathrm{cow}$ per day; Schroeder et al., 2002; and $700 \mathrm{~g} /$ cow per day; Salado et al., 2004) can increase milk fat content and yield. Milk fat yield depends on the balance between increase in dietary FA transfer to the mammary gland and decrease in de novo synthesis. A decline of FA synthesis within the mammary gland is often observed when supplemental FA sources are added to the diet of lactating dairy cows (Lock and Bauman, 2004).

Cheese contents $(\mathrm{g} / 100 \mathrm{~g})$ of fat $(18.2 \pm 2.6)$, protein $(27.3 \pm 1.1)$, TS $(52.6 \pm 2.2)$, and ash $(4.6 \pm 0.6)$ were not affected by dietary treatments. Fat contents were similar to those from low-fat Chanco cheeses reported by Brito et al. (2006). According to the Chilean norm for full-fat Chanco cheese (INN, 1999), the fat content is $25 \mathrm{~g} / 100 \mathrm{~g}$ of cheese. The low fat content of cheeses in the current experiment can be explained by the fat content of milk used for their manufacture. Because we wanted to measure effects of treatments on FA profile and sensory characteristics of cheeses, no standardization for milk fat content was used.

Compared with control and HVO, total C18:1 trans FA were increased in milk from cows fed SO. This is 
Table 3. Fatty acid composition of milk fat from cows fed control, soybean oil (SO), and hydrogenated vegetable oil (HVO) dietary treatments

\begin{tabular}{|c|c|c|c|c|c|}
\hline \multirow[b]{2}{*}{ FA $(\mathrm{g} / 100 \mathrm{~g}$ of FA) } & \multicolumn{3}{|c|}{ Diet $^{1}$} & \multirow[b]{2}{*}{ SED } & \multirow[b]{2}{*}{$P$-value } \\
\hline & Control & $\mathrm{SO}$ & HVO & & \\
\hline \multicolumn{6}{|l|}{ Saturated } \\
\hline $\mathrm{C} 4: 0$ & 2.30 & 1.96 & 2.44 & 0.11 & 0.24 \\
\hline $\mathrm{C} 6: 0$ & 1.47 & 1.05 & 1.34 & 0.08 & 0.08 \\
\hline $\mathrm{C} 8: 0$ & $0.95^{\mathrm{a}}$ & $0.61^{\mathrm{b}}$ & $0.82^{\mathrm{ab}}$ & 0.05 & 0.02 \\
\hline C10:0 & 4.91 & 5.48 & 7.23 & 1.37 & 0.78 \\
\hline C11:0 & 0.42 & 0.50 & 0.52 & 0.06 & 0.77 \\
\hline $\mathrm{C} 12: 0$ & $3.48^{\mathrm{a}}$ & $2.10^{\mathrm{b}}$ & $3.06^{\mathrm{ab}}$ & 0.20 & 0.01 \\
\hline $\mathrm{C} 13: 0$ & 0.34 & 0.47 & 0.47 & 0.07 & 0.73 \\
\hline $\mathrm{C} 14: 0$ & 12.2 & 9.69 & 9.98 & 0.56 & 0.13 \\
\hline C15:0 & 1.15 & 0.87 & 1.09 & 0.08 & 0.36 \\
\hline C16:0 & 33.78 & 27.15 & 31.78 & 1.39 & 0.13 \\
\hline $\mathrm{C} 17: 0$ & 0.45 & 0.58 & 0.51 & 0.04 & 0.51 \\
\hline $\mathrm{C} 18: 0$ & 6.21 & 6.94 & 6.26 & 0.38 & 0.71 \\
\hline $\mathrm{C} 20: 0$ & 0.16 & 0.26 & 0.30 & 0.06 & 0.64 \\
\hline $\mathrm{C} 21: 0$ & 0.09 & 0.43 & 0.19 & 0.07 & 0.15 \\
\hline $\mathrm{C} 23: 0$ & 0.22 & 0.33 & 1.08 & 0.24 & 0.31 \\
\hline $\mathrm{C} 24: 0$ & $0.03^{\mathrm{b}}$ & $0.02^{\mathrm{b}}$ & $0.27^{\mathrm{a}}$ & 0.03 & 0.004 \\
\hline \multicolumn{6}{|l|}{ Monounsaturated } \\
\hline C14:1 & 1.47 & 1.49 & 1.14 & 0.10 & 0.30 \\
\hline C15:1 & 0.18 & 0.21 & 0.15 & 0.01 & 0.15 \\
\hline C16:1 & 1.63 & 1.79 & 1.51 & 0.12 & 0.65 \\
\hline $\mathrm{C} 17: 1$ & 0.22 & 0.19 & 0.18 & 0.01 & 0.67 \\
\hline $\mathrm{C} 18: 1$ trans $-6+$ trans- 8 & 0.29 & 0.38 & 0.38 & 0.04 & 0.64 \\
\hline $\mathrm{C} 18: 1$ trans -9 & $0.39^{\mathrm{b}}$ & $1.19^{\mathrm{a}}$ & $0.35^{\mathrm{b}}$ & 0.15 & 0.03 \\
\hline $\mathrm{C} 18: 1$ trans -10 & $0.49^{\mathrm{b}}$ & $0.93^{\mathrm{a}}$ & $0.45^{\mathrm{b}}$ & 0.06 & $<0.001$ \\
\hline C18:1 trans-11 (vaccenic acid) & $1.53^{\mathrm{b}}$ & $4.44^{\mathrm{a}}$ & $1.33^{\mathrm{b}}$ & 0.40 & $<0.001$ \\
\hline C18:1 cis-9 & 18.95 & 20.86 & 16.51 & 0.89 & 0.13 \\
\hline $\mathrm{C} 24: 1 \mathrm{n}-9$ & 0.66 & 1.48 & 0.97 & 0.45 & 0.77 \\
\hline \multicolumn{6}{|l|}{ Polyunsaturated } \\
\hline $\mathrm{C} 18: 2$ trans $\mathrm{n}-6$ & 0.28 & 0.46 & 0.37 & 0.04 & 0.28 \\
\hline $\mathrm{C} 18: 2$ cis $\mathrm{n}-6$ & 3.19 & 3.02 & 2.47 & 0.15 & 0.14 \\
\hline C18:3 n-6 & 0.08 & 0.07 & 0.12 & 0.01 & 0.15 \\
\hline $\mathrm{C} 18: 3 \mathrm{n}-3$ & 0.42 & 0.51 & 0.35 & 0.05 & 0.46 \\
\hline C18:2 cis-9,trans-11 (rumenic acid) & 0.31 & 0.27 & 0.12 & 0.05 & 0.36 \\
\hline $\mathrm{C} 20: 2$ & 0.12 & 0.19 & 0.26 & 0.05 & 0.64 \\
\hline $\mathrm{C} 20: 3 \mathrm{n}-6$ & 0.14 & 1.65 & 0.17 & 0.42 & 0.30 \\
\hline $\mathrm{C} 20: 3 \mathrm{n}-3$ & 0.12 & 0.10 & 0.15 & 0.03 & 0.85 \\
\hline $\mathrm{C} 20: 4 \mathrm{n}-6$ & 0.62 & 0.37 & 0.21 & 0.14 & 0.57 \\
\hline $\mathrm{C} 22: 2$ & 0.12 & 0.15 & 1.64 & 0.48 & 0.34 \\
\hline $\mathrm{C} 20: 5 \mathrm{n}-3$ & 0.05 & 0.34 & 0.56 & 0.12 & 0.23 \\
\hline $\mathrm{C} 22: 6 \mathrm{n}-3$ & 0.65 & 1.88 & 3.28 & 0.76 & 0.39 \\
\hline SFA & $68.21^{\mathrm{a}}$ & $58.44^{\mathrm{b}}$ & $67.35^{\mathrm{a}}$ & 1.66 & 0.02 \\
\hline MUFA & $25.86^{\mathrm{b}}$ & $33.01^{\mathrm{a}}$ & $23.00^{\mathrm{b}}$ & 1.10 & $<0.001$ \\
\hline PUFA & 5.92 & 8.54 & 9.64 & 1.43 & 0.57 \\
\hline C18:1 trans & $2.71^{\mathrm{b}}$ & $6.96^{\mathrm{a}}$ & $2.52^{\mathrm{b}}$ & 0.51 & $<0.001$ \\
\hline Polyunsaturated n-3 & 1.19 & 2.74 & 4.28 & 0.82 & 0.32 \\
\hline Polyunsaturated n-6 & 4.16 & 5.21 & 3.32 & 0.46 & 0.26 \\
\hline$n-6 / n-3$ & 4.94 & 3.51 & 2.84 & 0.78 & 0.11 \\
\hline PUFA/SFA & $0.47^{\mathrm{b}}$ & $0.74^{\mathrm{a}}$ & $0.52^{\mathrm{ab}}$ & 0.04 & 0.04 \\
\hline Atherogenic index & 2.50 & 1.55 & 2.28 & 0.21 & 0.18 \\
\hline Thrombogenic index & $1.81^{\mathrm{a}}$ & $1.14^{\mathrm{b}}$ & $1.61^{\mathrm{a}}$ & 0.11 & 0.05 \\
\hline
\end{tabular}

${ }^{\mathrm{a}, \mathrm{b}}$ Means in the same row with different superscripts differ significantly for treatment effect with the $P$-value shown.

${ }^{1}$ Control $=$ no fat supplement; $\mathrm{SO}=500 \mathrm{~g} / \mathrm{d}$ per cow $\mathrm{HVO}=500 \mathrm{~g} / \mathrm{d}$ per cow.

due to the FA profile of the SO used in TMR preparation; increases in dietary $\mathrm{C} 18: 2$ and $\mathrm{C} 18: 3 \mathrm{FA}$ have been shown to enhance concentration of $\mathrm{C} 18: 1$ trans FA in milk through ruminal biohydrogenation (Bu et al., 2007). In the current study, milk VA was increased by $190 \%$ with SO compared with control and HVO; however, RA was not affected by treatment (Table 3 ). This concurs with the lack of treatment effect on the $\Delta^{9}$-desaturase index for C18:1 trans-11 and C18:2 cis9,trans-11 (0.19 \pm 0.09$)$. Dietary inclusion of unsaturated FA sources can increase VA in milk because they lead to an accumulation of VA in the rumen, which 
Table 4. Fatty acid composition of cheeses from cows fed control, soybean oil (SO), and hydrogenated vegetable oil (HVO) dietary treatments

\begin{tabular}{|c|c|c|c|c|c|}
\hline \multirow[b]{2}{*}{ FA $(g / 100 \mathrm{~g}$ of $\mathrm{FA})$} & \multicolumn{3}{|c|}{ Diet $^{1}$} & \multirow[b]{2}{*}{ SED } & \multirow[b]{2}{*}{$P$-value } \\
\hline & Control & $\mathrm{SO}$ & HVO & & \\
\hline \multicolumn{6}{|l|}{ Saturated } \\
\hline C4:0 & 2.11 & 1.71 & 2.58 & 0.16 & 0.06 \\
\hline C6:0 & $1.45^{\mathrm{ab}}$ & $1.00^{\mathrm{b}}$ & $1.72^{\mathrm{a}}$ & 0.12 & 0.02 \\
\hline $\mathrm{C} 8: 0$ & $0.91^{\mathrm{a}}$ & $0.56^{\mathrm{b}}$ & $0.99^{\mathrm{a}}$ & 0.07 & 0.01 \\
\hline C10:0 & 2.37 & 1.71 & 2.69 & 0.18 & 0.06 \\
\hline C11:0 & $0.31^{\mathrm{a}}$ & $0.18^{\mathrm{b}}$ & $0.31^{\mathrm{a}}$ & 0.02 & 0.04 \\
\hline $\mathrm{C} 12: 0$ & $3.38^{\mathrm{a}}$ & $2.04^{\mathrm{b}}$ & $3.35^{\mathrm{a}}$ & 0.24 & 0.007 \\
\hline $\mathrm{C} 13: 0$ & 0.14 & 0.07 & 0.10 & 0.01 & 0.06 \\
\hline C14:0 & $12.31^{\mathrm{a}}$ & $9.31^{\mathrm{b}}$ & $11.37^{\mathrm{ab}}$ & 0.54 & 0.04 \\
\hline C15:0 & 1.36 & 0.94 & 0.89 & 0.12 & 0.28 \\
\hline C16:0 & $35.27^{\mathrm{a}}$ & $28.29^{\mathrm{b}}$ & $38.82^{\mathrm{a}}$ & 1.82 & 0.02 \\
\hline $\mathrm{C} 17: 0$ & 0.50 & 0.44 & 0.37 & 0.03 & 0.24 \\
\hline C18:0 & 5.28 & 7.83 & 6.99 & 0.57 & 0.19 \\
\hline $\mathrm{C} 21: 0$ & $0.55^{\mathrm{b}}$ & $1.16^{\mathrm{a}}$ & $0.48^{\mathrm{b}}$ & 0.12 & 0.006 \\
\hline $\mathrm{C} 23: 0$ & 0.37 & 0.54 & 0.30 & 0.05 & 0.22 \\
\hline C24:0 & 0.28 & 0.24 & 0.18 & 0.05 & 0.81 \\
\hline \multicolumn{6}{|l|}{ Monounsaturated } \\
\hline C14:1 & 1.51 & 1.41 & 1.08 & 0.10 & 0.27 \\
\hline C15:1 & 0.13 & 0.16 & 0.18 & 0.01 & 0.47 \\
\hline C16:1 & 1.76 & 1.95 & 1.60 & 0.12 & 0.58 \\
\hline C17:1 & 0.24 & 0.20 & 0.17 & 0.02 & 0.49 \\
\hline $\mathrm{C} 18: 1$ trans $-6+$ trans -8 & 0.20 & 0.65 & 0.32 & 0.10 & 0.21 \\
\hline C18:1 trans -9 & $0.22^{\mathrm{b}}$ & $1.29^{\mathrm{a}}$ & $0.34^{\mathrm{b}}$ & 0.18 & 0.008 \\
\hline $\mathrm{C} 18: 1$ trans -10 & $0.35^{\mathrm{b}}$ & $0.73^{\mathrm{a}}$ & $0.41^{\mathrm{b}}$ & 0.06 & 0.01 \\
\hline C18:1 trans-11 (vaccenic acid) & $1.53^{\mathrm{b}}$ & $6.02^{\mathrm{a}}$ & $0.82^{\mathrm{b}}$ & 0.91 & 0.01 \\
\hline $\mathrm{C} 18: 1$ cis-9 & $16.48^{\mathrm{b}}$ & $20.74^{\mathrm{a}}$ & $19.26^{\mathrm{ab}}$ & 0.76 & 0.03 \\
\hline C24:1 n-9 & 1.13 & 0.68 & 0.11 & 0.28 & 0.38 \\
\hline \multicolumn{6}{|l|}{ Polyunsaturated } \\
\hline C18:2 trans $\mathrm{n}-6$ & $0.32^{\mathrm{b}}$ & $0.50^{\mathrm{a}}$ & $0.23^{\mathrm{b}}$ & 0.04 & 0.004 \\
\hline $\mathrm{C} 18: 2$ cis $\mathrm{n}-6$ & $3.80^{\mathrm{a}}$ & $4.74^{\mathrm{a}}$ & $2.62^{\mathrm{b}}$ & 0.34 & 0.009 \\
\hline $\mathrm{C} 18: 3 \mathrm{n}-6$ & 0.10 & 0.09 & 0.08 & 0.01 & 0.91 \\
\hline C18:3 n-3 & 0.30 & 0.37 & 0.24 & 0.02 & 0.09 \\
\hline C18:2 cis-9,trans-11 (rumenic acid) & 0.05 & 0.07 & 0.07 & 0.01 & 0.19 \\
\hline $\mathrm{C} 20: 2$ & 0.11 & 0.11 & 0.02 & 0.02 & 0.09 \\
\hline $\mathrm{C} 20: 3 \mathrm{n}-6$ & 0.24 & 0.34 & 0.18 & 0.03 & 0.19 \\
\hline $\mathrm{C} 22: 2$ & 0.06 & 0.06 & 0.03 & 0.01 & 0.51 \\
\hline $\mathrm{C} 20: 5$ n-3 & 0.16 & 0.39 & 0.08 & 0.10 & 0.48 \\
\hline $\mathrm{C} 22: 6 \mathrm{n}-3$ & 4.50 & 3.26 & 0.85 & 0.97 & 0.34 \\
\hline SFA & $66.65^{\mathrm{a}}$ & $56.10^{\mathrm{b}}$ & $71.20^{\mathrm{a}}$ & 2.47 & 0.006 \\
\hline MUFA & $22.70^{\mathrm{b}}$ & $34.48^{\mathrm{a}}$ & $24.61^{\mathrm{b}}$ & 1.93 & 0.001 \\
\hline PUFA & 9.74 & 10.00 & 4.44 & 1.32 & 0.14 \\
\hline C18:1 trans & $2.31^{\mathrm{b}}$ & $8.70^{\mathrm{a}}$ & $1.91^{\mathrm{b}}$ & 1.13 & $<0.001$ \\
\hline Polyunsaturated n-3 & 4.97 & 4.03 & 1.18 & 1.00 & 0.21 \\
\hline Polyunsaturated n-6 & $4.53^{\mathrm{ab}}$ & $5.71^{\mathrm{a}}$ & $3.11^{\mathrm{b}}$ & 0.42 & 0.01 \\
\hline$n-6 / n-3$ & 1.62 & 2.03 & 2.68 & 0.37 & 0.57 \\
\hline PUFA/SFA & $0.49^{\mathrm{b}}$ & $0.79^{\mathrm{a}}$ & $0.40^{\mathrm{b}}$ & 0.06 & 0.002 \\
\hline Atherogenic index & 0.83 & 0.43 & 1.36 & 0.17 & 0.08 \\
\hline Thrombogenic index & $1.11^{\mathrm{a}}$ & $0.69^{\mathrm{b}}$ & $1.39^{\mathrm{a}}$ & 0.12 & 0.04 \\
\hline
\end{tabular}

${ }^{\mathrm{a}, \mathrm{b}}$ Means in the same row with different superscripts differ significantly for treatment effect with the $P$-value shown.

${ }^{1}$ Control $=$ no fat supplement; $\mathrm{SO}=500 \mathrm{~g} / \mathrm{d}$ per cow $\mathrm{HVO}=500 \mathrm{~g} / \mathrm{d}$ per cow.

supplies more VA to the mammary gland for conversion to RA by the $\Delta^{9}$-desaturase enzyme (Kay et al., 2004).

In the current study, the saturated nature of HVO was reflected by the SFA content in milk; generally, inhibition of de novo mammary synthesis is more sensitive to unsaturated FA sources (Salado et al., 2004) such as SO. The proportions of C6:0, C8:0, C11:0, $\mathrm{C} 12: 0, \mathrm{C} 14: 0, \mathrm{C} 16: 0$, and $\mathrm{C} 21: 0$ in cheese were reduced with SO compared with control and HVO (Table 4). This is in agreement with Allred et al. (2006), who reported that milk and cheese concentrations of SFA were reduced when cows were fed Ca salts of palm or fish oils alone or in combination with soybean products (extruded full-fat soybean or soybean oil).

Cheese from cows fed SO had higher concentrations of $\mathrm{C} 18: 1$ cis-9 than control and HVO. In ruminants, 
approximately $40 \%$ of $\mathrm{C} 18: 0$ absorbed by the mammary gland is desaturated to C18:1 cis-9 (Lock and Garnsworthy, 2003). In humans, C18:1 cis-9 can prevent increased low-density lipoprotein in blood and can decrease blood pressure (Dhakal et al., 2014). Despite the fact that the risk of developing atherosclerosis or coronary thrombosis by consuming dairy fats is not definite (Chowdhury et al., 2014), dairy products with lower atherogenic and thrombogenic indices are less likely to be negative for human health (Allred et al., 2006). In the current study, the thrombogenic index was decreased with SO compared with control and HVO in both milk and cheese. The dietary lipids used in our study, specifically the SO, could be used to improve the nutritional quality and associated health value of milk and cheese from a human standpoint.

In the current study, sensorial attributes of Chanco cheese were not affected by dietary treatments. On a scale ranging from 0 to 9 , cheese attributes for holes $(2.05 \pm 0.47)$, bitter flavor $(2.7 \pm 0.68)$, greasiness $(2.12 \pm 0.13)$, screeching $(2.26 \pm 0.33)$, graininess $(2.66 \pm 0.38)$, and sharpness $(2.05 \pm 0.15)$ were of mild intensity, whereas color homogeneity $(6.03 \pm 0.26)$ and salty flavor $(4.98 \pm 0.59)$ were of high intensity. Cheddar cheeses from cows fed a mixture of fish and sunflower oils $(15+30 \mathrm{~g} / \mathrm{kg}$ of DM) were not different in terms of flavor, aroma, and overall impression (Jones et al., 2005). Similarly, Khanal et al. (2005) reported no difference in color, flavor, texture, and overall quality of Cheddar cheeses from grazing cows supplemented with a concentrate containing $75 \%$ full-fat extruded soybeans. Sympoura et al. (2009) supplemented dairy cows with extruded linseed and extruded linseed + $\alpha$-tocopherol; they reported that Saint-Nectaire cheeses from both supplements decreased the milk note for cheese flavor and odor. Ryhänen et al. (2005) used rapeseed oil as dietary supplement in dairy cows and found that, in comparison with their control, rapeseed oil changed the texture of Edam cheeses to a soft consistency. They mentioned that increases in the level of unsaturated FA in milk often results in softer cheese, but can also induce other defects such as sandiness, gumminess, pale color, and eye-formation problems. In the current study, concentrations of MUFA were increased in milk and cheese when cows were fed SO with no effect on cheese texture. Further research will be needed to test the effect of different times of cheese maturation because it is known that as cheese ages its flavor characteristics change, especially if the cheese is rich in unsaturated FA (such as those produced from SO; Allred et al., 2006).

Compared with control and HVO, dietary supplementation with SO (500 g/d per cow) in dairy cows increased VA and MUFA concentrations and decreased
SFA concentration and thrombogenic index of milk and cheese without negative effects on milk and cheese composition and sensory characteristics of cheese.

\section{ACKNOWLEDGMENTS}

This study was sponsored by a research grant from FONDECYT 11121142 (Fondo Nacional de Desarrollo Científico y Tecnológico, Chile). We thank the staff from the Departamento de Ciencias Animales: Juanita Clavijo, Jorge Manzor, and Pamela Alvarez for technical assistance and Fundación Agro U.C. (Pirque, Chile) for the animal facilities and assistance in obtaining research data.

\section{REFERENCES}

Allred, S. L., T. R. Dhiman, C. P. Brennand, R. C. Khanal, D. J McMahon, and N. D. Luchini. 2006. Milk and cheese from cows fed calcium salts of palm and fish oil alone or in combination with soybean products. J. Dairy Sci. 89:234-248. http://dx.doi. org/10.3168/jds.S0022-0302(06)72088-4.

AOAC. 1984. Official Methods of Analysis. 14th ed. AOAC, Arlington, $\mathrm{VA}$

AOAC. 1990. Official Methods of Analysis. 15th ed. AOAC, Arlington, VA.

AOAC International. 2000. Official Method of Analysis. 17th ed AOAC International, Arlington, VA.

Brito, C., X. Manriquez, L. H. Molina, and M. Pinto. 2003. Maturation study of low fat Chanco cheese made with homogenized milk. Arch. Latinoam. Nutr. 53:299-305.

Brito, C., P. Uribe, L. H. Molina, I. Molina, and M. Pinto. 2006. Production of low-fat Chanco cheese using homogenized milk and adjunct lactic culture. Int. J. Dairy Technol. 59:242-249. http:// dx.doi.org/10.1111/j.1471-0307.2006.00281.x.

BSI (British Standards Institution). 1969. Gerber method for the determination of fat in milk and milk products. British Standards 696: Part 2. British Standards Institution, London, UK.

Bu, D. P., J. Q. Wang, T. R. Dhiman, and S. J. Liu. 2007. Effectiveness of oils rich in linoleic and linolenic acids to enhance conjugated linoleic acid in milk from dairy cows. J. Dairy Sci. 90:998-1007. http://dx.doi.org/10.3168/jds.S0022-0302(07)71585-0.

Chowdhury, R.. S. Warnakula, S. Kunutsor, F. Crowe, H. A. Ward, L. Johnson, O. H. Franco, A. S. Butterworth, N. G. Forouhi, S. G. Thompson, K. T. Khaw, D. Mozaffarian, J. Danesh, and E. Di Angelantonio. 2014. Association of dietary, circulating, and supplement fatty acids with coronary risk a systematic review and meta-analysis. Ann. Intern. Med. 160:398-406. http://dx.doi. org/10.7326/M13-1788.

Dhakal, K. H., K. H. Jung, J. H. Chae, J. G. Shannon, and J. D. Lee 2014. Variation of unsaturated fatty acids in soybean sprout of high oleic acid accessions. Food Chem. 164:70-73. http://dx.doi. org/10.1016/j.foodchem.2014.04.113.

Instituto Nacional de Normalización (INN). 1999 Productos lácteos, queso Chanco. Requisitos. Norma Chilena 2090. Instituto Nacional de Normalización, Santiago, Chile.

ISO. 2003. Sensory analysis - General guidance for establishing a sensory profile ISO Standard 13299. International Organization for Standardization (ISO), Geneva, Switzerland.

ISO. 2007. Sensory analysis - General guidance for the design of test rooms. ISO Standard 8589, International Organization for Standardization (ISO), Geneva, Switzerland.

Jacobs, A. A. A., J. van Baal, M. A. Smits, H. Z. H. Taweel, W. H. Hendriks, A. M. van Vuuren, and J. Dijkstra. 2011. Effects of feeding rapeseed oil, soybean oil, or linseed oil on stearoyl-CoA desaturase expression in the mammary gland of dairy cows. J. Dairy Sci. 94:874-887. http://dx.doi.org/10.3168/jds.2010-3511. 
Jones, E. L., K. J. Shingfied, C. Kohen, A. K. Jones, B. Lupoli, A. S. Grandison, D. E. Beever, C. M. Williams, P. C. Calder, and P. Yaqoob. 2005. Chemical, physical, and sensory properties of dairy products enriched with conjugated linoleic acid. J. Dairy Sci. 88:2923-2937. http://dx.doi.org/10.3168/jds.S00220302(05)72973-8.

Kargar, S., G. R. Ghorbani, M. Alikhani, M. Khorvash, L. Rashidi, and D. J. Schingoethe. 2012. Lactational performance and milk fatty acid profile of Holstein cows in response to dietary fat supplements and forage:concentrate ratio. Livest. Sci. 150:274-283. http://dx.doi.org/10.1016/j.livsci.2012.09.015.

Kay, J. K., T. R. Mackle, M. J. Auldist, N. A. Thomson, and D. E. Bauman. 2004. Endogenous synthesis of cis-9, trans-11 conjugated linoleic acid in dairy cows fed fresh pasture. J. Dairy Sci. 87:369378. http://dx.doi.org/10.3168/jds.S0022-0302(04)73176-8.

Khanal, R. C., T. R. Dhiman, A. L. Ure, C. P. Brennand, R. L. Boman, and D. J. McMahon. 2005. Consumer acceptability of conjugated linoleic acid enriched milk and cheddar cheese from cows grazing on pasture. J. Dairy Sci. 88:1837-1847. http://dx.doi. org/10.3168/jds.S0022-0302(05)72858-7.

Lock, A. L., and D. E. Bauman. 2004. Modifying milk fat composition of dairy cows to enhance fatty acids beneficial to human health Lipids 39:1197-1206. http://dx.doi.org/10.1007/s11745-004-13486.

Lock, A. L., and P. C. Garnsworthy. 2002. Independent effects of dietary linoleic and linolenic fatty acids on the conjugated linoleic acid content of cows' milk. Anim. Sci. 74:163-176.

Lock, A. L., and P. C. Garnsworthy. 2003. Seasonal variation in milk conjugated linoleic acid and delta(9)-desaturase activity in dairy cows. Livest. Prod. Sci. 79:47-59.

Lynch, J. M., A. L. Lock, D. A. Dwyer, R. Noorbakhash, D. M. Barbano, and D. E. Bauman. 2005. Flavor and stability of pasteurized milk with elevated levels of conjugated linoleic acid and vaccenic acid. J. Dairy Sci. 88:489-498. http://dx.doi.org/10.3168/jds. S0022-0302(05)72711-9.

NRC. 2001. Nutrient Requirements of Dairy Cattle. 7th rev. ed. Natl. Acad. Sci., Washington, DC

Ryhänen, E. L., K. Tallavaara, J. M. Griinari, S. Jaakkola, S. MantereAlhonen, and K. J. Shingfield. 2005. Production of conjugated linoleic acid enriched milk and dairy products from cows receiving grass silage supplemented with a cereal-based concentrate containing rapeseed oil. Int. Dairy J. 15:207-217. http://dx.doi. org/10.1016/j.idairyj.2004.07.003.

Salado, E. E., G. A. Gagliostro, D. Becu-Villalobos, and I. LacauMengido. 2004. Partial replacement of corn grain by hydrogenated oil in grazing dairy cows in early lactation. J. Dairy Sci. 87:12651278. http://dx.doi.org/10.3168/jds.S0022-0302(04)73277-4.

Salter, A. M. 2013. Dietary fatty acids and cardiovascular disease. Animal 7:163-171. http://dx.doi.org/10.1017/S1751731111002023.

Schroeder, G. F. G. A. Gagliostro, D. Becu-Villalobos, and I. LacauMengido. 2002. Supplementation with partially hydrogenated oil in grazing dairy cows in early lactation. J. Dairy Sci. 85:580-594. http://dx.doi.org/10.3168/jds.S0022-0302(02)74112-X.

Selner, D. R., and L. H. Schultz. 1980. Effects of feeding oleic-acid or hydrogenated vegetable-oils to lactating cows. J. Dairy Sci. 63:12351241. http://dx.doi.org/10.3168/jds.S0022-0302(80)83074-8.

Shingfield, K. J., M. Bonnet, and N. D. Scollan. 2013. Recent developments in altering the fatty acid composition of ruminantderived foods. Animal 7:132-162. http://dx.doi.org/10.1017/ S1751731112001681.

Stamey, J. A., D. M. Shepherd, M. J. de Veth, and B. A. Corl. 2012. Use of algae or algal oil rich in n-3 fatty acids as a feed supplement for dairy cattle. J. Dairy Sci. 95:5269-5275. http://dx.doi. org/10.3168/jds.2012-5412.

Sympoura, F., A. Cornu, P. Tournayre, T. Massouras, J. L. Berdagué, and B. Martin. 2009. Odor compounds in cheese made from the milk of cows supplemented with extruded linseed and $\alpha$-tocopherol. J. Dairy Sci. 92:3040-3048. http://dx.doi.org/10.3168/jds.20081802.

Ulbricht, T. L., and D. A. Southgate. 1991. Coronary heart disease: seven dietary factors. Lancet 338:985-992. http://dx.doi. org/10.1016/0140-6736(91)91846-M.

Zheng, H. C., J. X. Liu, J. H. Yao, Q. Yuan, H. W. Ye, J. A. Ye, and Y. M. Wu. 2005. Effects of dietary sources of vegetable oils on performance of high-yielding lactating cows and conjugated linoleic acids in milk. J. Dairy Sci. 88:2037-2042. http://dx.doi.org/10.3168/ jds.S0022-0302(05)72880-0. 